\title{
RETRATO DE MEL
}

Berman Bans

(c) UNAN-Managua

Recibido: mayo 2017

Aprobado: junio 2017

(c) $(7)$ (2)

También le dije que esas cosas no me pondrían celoso. Que estaba muy seguro de mí mismo y de ella. O de lo que se supone que sentía ella. Esa promesa improbable, absurda, que aún nos mantenía juntos. A ella, estudiante de derecho salida de los suburbios, caminando por las bulliciosas calles de Salamanca, hablando idioteces turísticas con sus compañeros becarios. A mí, sometido a los calores de Managua, corrigiendo exámenes de adolescentes insulsos, a miles de kilómetros de distancia durante casi dos años. Separados, pero ¿juntos?. La gracia tramposa del ciberespacio. Que no era celoso. Que me sentía seguro. Eso, al principio, debió convencerla de estar tratando con alguien diferente a su último novio. Seis años de codependencias y paranoias arcaicas. Su debilidad por los músicos. Su tendencia a los bacanales. Melisa era edecana, aunque siempre dijo que era modelo, de Redbull, y él era el DJ exclusivo de ciertos eventos promocionales de la marca. La comida y las ganas de comer. Luego de dos años de pasión, vino la rutina, el vacío, y otra vez el hambre. Cuatro años de posponer continuamente el matrimonio. El último año se encontraban apenas una vez al mes. Y la cama ya no era el mismo jolgorio. En secreto habían entrado, Melisa dixit, en las costumbres menospreciables. Seis años del mismo disco angustioso. Qué le habrá visto a ese tico banal de promesas irresponsables. Ahí dejó su virginidad y la práctica de su cristianismo católico. Gran cosa. Para Mel era mucho. ¿Qué habrá visto en mí? Ah, claro. Las charlas motivacionales. La posibilidad de autoexplorarse. Acaso vio al huraño profesor de literatura, al padre ausente, al niño escondido detrás de uniformes estúpidos. Alguien a quien proteger o bajo quien protegerse. Imposible que se fijara solamente en la camisa de franela, en los desteñidos azulones ligeramente rasgados, de nuestra primera cita en esa heladería de ventanales rotos. Aunque la primera vez que me habló en confianza, para pedirme el número, le gustó la manera en que el color de mi cabello combinaba con mis ojos. Eso lo dijo luego. Más bien lo escribió por inbox, confesión tardía, al otro lado del océano. Dijo que esa tarde ya sospechaba estar hasta donde no era conmigo. Un mes después, vía skype, terminó con su novio. ¿Qué se sentirá poner un set tras otro de música tecno, ese ritmo impersonal para borregos, teniendo el corazón roto?

Ahora se va de Tapas con sus amigos. Dos mexicanos, una rumana y un bieloruso. Que no me pusiera celoso. Bulliciosas charlas, estúpidas, de proporciones babilónicas. Melisa y sus amigos. De Tapas todos. Destapándose hasta el colmo del narcisismo clase mediero dudosamente exitoso. Y ahí el Señor

Tengopenedeinfantenegrete. El fresita de Jalisco que le tiró el cuento los primeros tres meses hasta que desistió, convencido de que era lesbiana. Melisa sáfica. Melisa lésbica. Melepigramática. Tortillera. Comecoños. Esa era la rumana. Y que no me pusiera celoso. Tranquila. Disfrutá. Luego me contás cómo te fue en tu destapadera frustradora de libidos. Que me siento, ¿sentía?, seguro. Hypocritón mentiroso. El retrato de Mel en la sala de su casa: una colochona anteojuda de unos cinco años metida en su bikini fucsia, brazos en jarra, los labios algo gruesos desafiando a la cámara, el cabello enredado como la cabeza de medusa, la mirada petrificante detrás de los anteojos. 
¿Quién te enseñó a posar asi? Nadie. Desde entonces era así de coqueta. Edecana junior. Nadie. No body. Nadie Mel te enseñó a seducir. Nadie. Ese era el personaje a nombrar si le hubiese preguntado si ya le gustaba alguien en Salamanca. Por eso nunca se lo pregunté. No soy celoso. Estoy seguro de mí. Andá disfrutá. Qué madurez de novio. Pero si aparece alguien me contás. Y el emoticón con la lengua de fuera para hacerla sonreir. Me contás cualquier cosa interesante que suceda. Me servirá para el relato sobre becarios que quiero escribir. Observar bien el ambiente, a los hipsters de ese zoológico. Analizar hábitos esperpénticos. Apuntá en tu mente. Sos mi corresponsal. Mi Virginia Woolf funesta. Sandeces de esas. Frases estúpidamente complacientes. ¿Se las creía de verdad? Lo de su compañera andaluza bisexual era una verdadera cantera. Pero no andaba ganas de escribir cuentos inspirados en el realismo sucio. Andá disfrutá de los bares cerveceros, de los flirteos intensos, de la música tecno. Qué imbécil. Nunca necesité decírselo.

Melisa era una maestra de los goces nocturnos. 